\title{
Investigating the use of Landsat thematic mapper data for estimation of forest leaf area index in southern Sweden
}

\author{
L. Eklundh, K. Hall, H. Eriksson, J. Ardö, and P. Pilesjö
}

\begin{abstract}
The study aims at investigating the use of Landsat thematic mapper (TM) for mapping leaf area index (LAI) in coniferous and deciduous forests in southern Sweden. LAI has been estimated in the field with optical measurements, allometric equations, and litter-trap data, and empirical relationships between LAI estimates and satellite-measured reflectances have been analysed. Several common vegetation indices and multiple regressions where estimated LAI is predicted as a function of various spectral bands are tested. The results indicate significant relationships between Landsat TM reflectances and parameters related to LAI, and the relationships are improved when separating coniferous and deciduous stands. The best relationships occur between Landsat TM data and the product of effective LAI as estimated with the LAI-2000 instrument and a needle clumping factor $\left(L_{\mathrm{G}}\right)$, which explains about $80 \%$ of the variation in coniferous stands and about $50 \%$ of the variation in deciduous stands. The best single bands in coniferous stands are the middle-infrared bands (TM5 and TM7), and the best vegetation index is the moisture stress index (TM5/TM4). The best single band in deciduous stands is TM4, and the best vegetation index is the simple ratio (SR).
\end{abstract}

Résumé. L'objectif de cette étude est de faire le point sur l'utilisation de Landsat-TM pour la cartographie de l'indice de surface foliaire (LAI) dans des forêts de conifères et de feuillus du Sud de la Suède. L'indice LAI a été estimé sur le terrain à l'aide de mesures optiques, d'équations allométriques et des données de pièges à litière, et des relations empiriques entre les estimations de LAI et les réflectances mesurées par satellite ont été analysées. Plusieurs indices de végétation couramment utilisés et des régressions multiples basées sur des estimations de LAI dérivées en fonction de diverses bandes spectrales sont testées. Les résultats montrent qu'il y a des relations significatives entre les réflectances Landsat-TM et les paramètres reliés au LAI, et que ces relations se bonifient lorsque l'on sépare les peuplements de conifères et de feuillus. Les meilleures relations sont observées entre les données Landsat-TM et les estimations du produit de LAI tel qu'estimé à l'aide de l'instrument LAI-2000 et d'un facteur d'agrégation des aiguilles $\left(L_{\mathrm{G}}\right)$, ce qui permet d'expliquer approximativement $80 \%$ de la variation dans les peuplements de conifères et environ $50 \%$ de la variation dans les peuplements de feuillus. Les meilleures bandes uniques pour les peuplements de conifères sont les bandes du moyeninfrarouge (TM5 et TM7) et le meilleur indice de végétation est l'indice « moisture stress » (TM5/TM4). Pour les peuplements de feuillus, la meilleure bande unique est la bande TM4 et le meilleur indice de végétation est l'indice SR (« simple ratio »).

[Traduit par la Rédaction]

\section{Introduction}

The forest biome covers extensive areas and is of major interest for its role in the assimilation and fixing of atmospheric carbon (Running and Nemani, 1988; Chen et al., 1997). Carbon is stored in the soil and as biomass, and an important part of the exchange with the atmosphere occurs by means of the leaves of trees. The leaf area affects the potential amount of light intercepted by the plants and thereby regulates growth and carbon assimilation (Bonan, 1993; Stenberg et al., 1994a; Goetz and Prince, 1996; Medlyn, 1998). Carbon fluxes over forests can be accurately measured at single sites using flux towers (Grelle and Lindroth, 1996), and models have been developed for determining forest ecophysiological processes (e.g., Running and Gower, 1991; Comins and McMurtrie, 1993; Landsberg and Waring, 1997). To estimate regional and national carbon budgets there is a need for information about the spatial distribution of structural and functional vegetation components, including leaf area index (LAI), which is defined as half of the total amount of leaf surface area per unit ground area (Chen and Black, 1992). The spatially heterogeneous nature of forests and the need to cover large areas mean that satellite remote sensing may be useful. The possibility of estimating forest LAI from satellite sensor data has been investigated by several researchers (e.g., Running and Nemani, 1988; Chen and Cihlar, 1995; 1996; Cihlar et al., 1997). LAI has been mapped in Scandinavian coniferous forests by Gemmel and Varjo (1999), Nilson et al. (1999), and Eklundh et al. (2001) using Landsat thematic mapper (TM) and enhanced thematic mapper plus (ETM+).

The aim of this study is to investigate the potential of Landsat-5 TM data for estimating LAI in deciduous and

Received 20 June 2002. Accepted 3 December 2002.

L. Eklundh, ${ }^{1}$ K. Hall, H. Eriksson, J. Ardö, and P. Pilesjö. Department of Physical Geography and Ecosystems Analysis, Lund University, Box 118, S-221 00 Lund, Sweden.

${ }^{1}$ Corresponding author (e-mail: lars.eklundh@ nateko.lu.se). 
coniferous forests in southern Sweden. Various estimates of LAI have been made in coniferous and deciduous forest stands, and the statistical relationships with satellite-derived reflectances are investigated. The current study is made within the framework of a research programme concerning the carbon balance in Swedish forests, in which there is a need for largearea collection of information on coniferous and deciduous forest LAI.

\section{Background}

\section{Remotely sensed data and leaf area index (LAI)}

Reflected radiation from homogeneous vegetation canopies is related to LAI (Tucker and Sellers, 1986). Relationships between LAI estimates and vegetation indices such as the normalized difference vegetation index (NDVI) derived from satellite sensor data have been observed in several studies (e.g., Spanner et al., 1990a; 1990b; Curran et al., 1992; Nemani et al., 1993; Chen and Cihlar, 1996; Turner et al., 1999; Boyd et al., 2000; Gupta et al., 2000, Chen et al., 2002). The relationships are affected by various factors, including canopy closure, understorey vegetation and soil reflectance (Spanner et al., 1990a), and variations in shadow patterns (Peddle et al., 1999). Relationships between LAI and middle infrared (MIR) reflectance have been found for boreal forests using Landsat TM and National Oceanic and Atmospheric Administration (NOAA) advanced very high resolution radiometer (AVHRR) data (Nemani et al., 1993; Nilson et al., 1999; Boyd et al., 2000; Brown et al., 2000; Eklundh et al., 2001). Reflectances in the MIR wavelengths decrease with increased leaf area, as a consequence of increased absorption due to water in the canopies. Boyd et al. (2000) formulated a variation of the NDVI, named VI3, in which the red band of the NDVI was replaced with the MIR band of the AVHRR sensor. To account for differences in understorey and canopy closure, Nemani et al. (1993) applied a different type of MIR modification to the NDVI. The modification was also applied to the simple ratio ( $\mathrm{SR}=\mathrm{NIR} / \mathrm{red}$, where NIR is near-infrared reflectance) by Brown et al. (2000). MIR information is also used in the moisture stress index (MSI = TM5/TM4, where TM4 and TM5 are reflectances in TM bands 4 and 5), which has been used for detection and mapping of forest decline and defoliation, both in deciduous and coniferous forests (Vogelmann, 1990). The MSI is thought to measure not one but several, largely inseparable, vegetation properties such as biomass, damage, and water content. The inverse relationship between MIR reflectance and biomass (Ardö, 1992), canopy closure (Butera, 1986), and vegetation density (Horler and Ahern, 1986) indicates that the MSI may also be useful for estimating LAI.

We have quoted several studies relating remotely sensed data with LAI; however, it should be pointed out that these are often based on different methods for estimating LAI in the field that may not always be comparable. Some of these methods are mentioned in the next section.

\section{Field-based LAI-estimation techniques}

Estimating LAI using destructive field measurements is labour intensive. Empirical relationships between needle biomass and stand parameters have been established for pine (Pinus sylvestris) and spruce (Picea abies) in Sweden (Marklund, 1988) but are not generally available for deciduous trees. For deciduous forest stands it is possible to capture the leaves in litter traps (Fassnacht et al., 1997) and utilize empirical relationships between dry weight and leaf area to estimate the total stand leaf area.

Indirect LAI estimation based on light-interception measurements can also be used. This method is nondestructive and considerably more rapid and can be used for following the phenological development throughout the season. The technique is based on the relationship between transmitted light and LAI. Simultaneous measurements of light are made below and above the canopy, and a relationship based on Millers theorem can be used (Miller, 1967; Welles, 1990; Chen and Black, 1991):

$$
L_{\mathrm{e}}=2 \int_{0}^{\pi / 2}-\ln [T(\theta)] \cos (\theta) \sin (\theta) \mathrm{d} \theta
$$

where $L_{\mathrm{e}}$ is an estimate of the effective LAI (the product of LAI and a foliage clumping index; Black et al., 1991), $T(\theta)$ is the transmitted non-intercepted radiation, and $\theta$ is the view zenith angle (the expression assumes that transmission is independent of azimuth). Measurements based on this principle have been made in boreal forests by several authors (Stenberg et al., 1994b; Smolander and Stenberg, 1996; Chen et al., 1997; Kucharik et al., 1998).

The effective LAI is only indirectly related to true LAI because of various levels of foliage clumping in the stand. In conifers, needles are clustered, forming shoots, rather than randomly distributed in the canopy (Gower and Norman, 1991; Stenberg et al., 1994b). It is recommended that the $L_{\mathrm{e}}$ values be multiplied by a conversion factor to account for this effect (Gower and Norman, 1991; LI-COR, Inc., 1992). In both deciduous and coniferous stands foliage clumping due to branches and irregular tree distribution also occurs (Nilson, 1971; Ross, 1981; Chen et al., 1997). Light transmission measurements are not only affected by photosynthetically active biomass, but also by stems, branches, and dead tissue in the canopy. In dense canopies, however, most of the stems, branches, and dead tissue are shaded by the live needles, and the influence of this material on the light transmission measurements may be limited (Gower et al., 1999). Methods for converting from $L_{\mathrm{e}}$ to LAI have been developed by Chen (1996) and Kucharik et al. (1998) (see the Methodology section). 


\section{Study sites and data}

\section{Study sites}

The study area is located in Skåne, southern Sweden, at about $55^{\circ} 45^{\prime} \mathrm{N}, 13^{\circ} 30^{\prime} \mathrm{E}$, where 67 forest stands (coniferous, deciduous, and mixed) distributed over an area of approximately $60 \times 60 \mathrm{~km}$ were sampled during the growing season of 2000. The dominant tree species in the study area are Norway spruce (Picea abies), beech (Fagus sylvatica), oak (Quercus robur), birch (Betula spp.), and ash (Fraxinus excelsior). The ground vegetation is dominated by herbs and grasses in the deciduous stands, very sparse mosses in the spruce stands, and sparse grasses in the pine stands.

\section{Remotely sensed data}

Only one fairly cloud-free Landsat image could be identified for the growing season of 2000, recorded on June 10. This Landsat-5 image was geometrically corrected against a digital topographic map at a scale of $1: 50000$, with a standard error of about one pixel $(30 \mathrm{~m})$. A radiometric correction and computation of at-satellite reflectances was done according to the methodology in Markham and Barker (1987), and with calibration coefficients from the Landsat data header of the image. The study area is generally flat, and no topographic correction was made to the data. Bandwidths of the TM sensor are given in Kramer (1996). Mean at-satellite spectral reflectances for the reflective channels of the TM sensor were computed as averages of $3 \times 3$ pixels centred over the studied forest plots. The averages were then adjusted for atmospheric effects using the $6 \mathrm{~S}$ radiative transfer model (Vermote et al., 1997). Values of water vapour, ozone, and optical thickness were obtained from the Swedish Meteorological and Hydrological Institute (SMHI). Optical thickness was computed from pyrheliometer data from Lund, which is located at a maximum distance of about $50 \mathrm{~km}$ from the field area. A modified computer implementation of the $6 \mathrm{~S}$ code was used (Antunes, 2001). Atmospheric input data are given in Table 1. Parts of the satellite scene were affected by clouds and cloud shadows, but plots in these areas were eliminated from the analysis.
Table 1. Parameters used for the $6 \mathrm{~S}$ atmospheric correction.

\begin{tabular}{ll}
\hline Water content & $1.96 \mathrm{~g} \cdot \mathrm{cm}^{-2}$ \\
Ozone content & $0.30 \mathrm{~cm} \cdot \mathrm{atm}$ \\
Visibility & $31.9 \mathrm{~km}$ \\
Optical thickness at $550 \mathrm{~nm}$ & 0.174 \\
Aerosol model & Maritime \\
Solar zenith angle & $36.1^{\circ}$ \\
Solar azimuth angle & $147.0^{\circ}$ \\
\hline
\end{tabular}

\section{Methodology}

\section{Optically based estimation of LAI}

The main data set for comparing optically based LAI estimates with Landsat TM data was collected during a field campaign. Sampling was carried out during the peak of the growing period of 2000 (late July) in all 67 stands. All plots were $100 \times 100 \mathrm{~m}$, and about 75 evenly distributed LAI-2000 measurements were made in each plot. In addition, basic stand parameters, such as tree density, species distribution, tree height, breast-height diameter $\left(D_{\mathrm{bh}}\right)$, crown radius, and crown height, were sampled in subplots (100-400 $\mathrm{m}^{2}$ depending on the tree density) in the centre of each plot. A summary of the forest stand data is given in Table 2.

Effective LAI was estimated using the LI-COR, Inc. LAI2000 instrument and the $\mathrm{C} 2000$ processing software (Welles, 1990; LI-COR, Inc., 1992). Optical measurements were carried out with two instruments, one with an open-sky view, and one below the canopy. Three methods were used to estimate onesided LAI $(L)$ from these measurements. The first method is a simple correction for needle clumping according to Gower and Norman (1991):

$$
L_{\mathrm{G}}=L_{\mathrm{e}} \gamma_{\mathrm{e}}
$$

where $L_{\mathrm{G}}$ is one-sided $\mathrm{LAI}^{2}, L_{\mathrm{e}}$ is the effective LAI as estimated by the LAI-2000 using a discrete approximation to Equation (1), and $\gamma_{\mathrm{e}}$ is the ratio of needle area to shoot area accounting for the fact that needles are clumped in conifer shoots. For broadleaf species, $L_{\mathrm{G}}$ equals $L_{\mathrm{e}}$.

Table 2. Statistics for the analysed plots.

\begin{tabular}{|c|c|c|c|c|}
\hline & Deciduous & Coniferous & Mixed & All \\
\hline No. of plots & 42 & 19 & 6 & 67 \\
\hline Tree density (trees $\cdot \mathrm{ha}^{-1}$ ) & $1005(95-6000)$ & $840(64-1601)$ & $700(254-1400)$ & $928(64-6000)$ \\
\hline Breast-height diameter, $D_{\mathrm{bh}}(\mathrm{cm})$ & $25(7-58)$ & $26(18-39)$ & $22(12-36)$ & $25(7-58)$ \\
\hline Tree height $(\mathrm{m})$ & $17(5-35)$ & $21(15-27)$ & $16(6-28)$ & $18(5-35)$ \\
\hline Crown height $(\mathrm{m})$ & $10.5(2.4-25.1)$ & $9.3(3.8-13.5)$ & $8.5(3.7-19.7)$ & $10.0(2.4-25.1)$ \\
\hline Crown diameter $(\mathrm{m})$ & $5.7(1.3-11.5)$ & $3.6(2.6-4.4)$ & $3.7(2.8-5.7)$ & $5.0(1.3-11.5)$ \\
\hline
\end{tabular}

Note: The values in the table are averages, with ranges in parentheses.

\footnotetext{
${ }^{2}$ Symbols used in Equations (2)-(4) differ somewhat from those used in the original articles (see also Table 3).
} 
The second method follows Chen (1996) and estimates the one-sided LAI of the canopy as

$$
L_{\mathrm{C}}=\frac{(1-\alpha) L_{\mathrm{e}} \gamma_{\mathrm{e}}}{\Omega_{\mathrm{e}}}
$$

where $L_{\mathrm{C}}$ is one-sided LAI, $\alpha$ is the ratio of woody area to total plant area $\left(W / L_{\mathrm{t}}\right)$, and $\Omega_{\mathrm{e}}$ is the element clumping index quantifying the effect of foliage clumping at scales larger than the shoot (i.e., branches and trees).

The third method follows Kucharik et al. (1998). LAI is estimated with the following equation:

$$
L_{\mathrm{K}}=\frac{\left\{L_{\mathrm{e}}(\theta)-\delta\left(f_{\mathrm{L}}\right) B\left[\Omega_{\mathrm{b}}(35)\right] \gamma_{\mathrm{e}}\right\}}{\Omega_{\mathrm{e}}(35)}-S
$$

where $L_{\mathrm{K}}$ is one-sided LAI; $L_{\mathrm{e}}(\theta)$ is the effective LAI as measured by the LAI-2000 at angle $\theta ; \delta\left(f_{\mathrm{L}}\right)$ is the fraction of the branch hemi-surface area index that is exposed to gaps, and therefore intercepts light in the canopy; $B$ is the hemi-surface area index of branches; $\Omega_{\mathrm{b}}(35)$ is the nonrandomness correction factor for branches obtained with a mean zenith view angle of $35^{\circ}$ (approximately the average LAI-2000 view angle ${ }^{3}$ ); $\Omega_{\mathrm{e}}(35)$ is the nonrandomness correction factor for shoots obtained with a mean zenith view angle of $35^{\circ}$; and $S$ is the hemi-surface area index of tree stems.

Data on needle-to-shoot relationships for pine and spruce $\left(\gamma_{\mathrm{e}}\right)$ were taken from Stenberg (1996), and data on branch area index (B) were taken from Nilson (1999). For mixed plots, $\gamma_{\mathrm{e}}$ was weighted according to the volume of tree crowns (crown height $\times$ crown area $\times$ number of crowns) of different species. The two latter correction methods (Equations (3) and (4)) rely on data from other optical instruments for assessing the clumping effects, such as the tracing radiation and architecture of canopies (TRAC) (Chen and Cihlar, 1995), or the multiband vegetation imager (MVI) (Kucharik et al., 1998). Since such measurements were not available, a simplified approach for assessing the clumping index was used according to Kucharik et al. (1999). The method involves the use of LAI-2000 readings from the central optical ring, looking towards the zenith, together with basic stand data such as stem density and stem diameter.

\section{Allometric relationships for estimating LAI}

Leaf area index was estimated from allometric relationships in pine and spruce stands. Needle biomass was estimated from multiple regressions based on stem diameter, tree height, crown height, and geographical location (pine only) (Marklund, 1988). To convert to LAI, values on specific leaf area (SLA, area per mass of dry leaves) of $4.5 \mathrm{~mm}^{2} \cdot \mathrm{mg}^{-1}$ for spruce and $7.3 \mathrm{~mm}^{2} \cdot \mathrm{mg}^{-1}$ for pine were used (Lagergren and Lindroth, 2002). Unfortunately, data on allometric relationships for the deciduous species in our study were not available.

Different symbols are used for one-sided LAI to distinguish between the various estimates (Table 3 ).

\section{Litter-fall collection}

Litter fall was collected in five deciduous stands as an independent data set for testing the various optically based LAI measures. This process is time-consuming and therefore could only be done in the stands listed in Table 4. These deciduous stands are situated within the main study area and were sampled during 2000 and 2001. The stands were selected in homogeneous and flat areas, and with one dominating tree species. Ten litter traps per plot were installed in 2000 in random locations, about $1 \mathrm{~m}$ above the ground. The traps are nearly circular with a diameter of about $50 \mathrm{~cm}$. In 2001 the number of traps was increased to $15-20$ per plot. Specific leaf area was calculated for each plot by harvesting leaves of various sizes from various heights in the canopies. The fresh leaf area was measured, and the leaves were weighted after drying at $75^{\circ} \mathrm{C}$ for $24 \mathrm{~h}$. Means and standard deviations of SLA are given in Table 4. To prevent disturbance and minimize reduction by decomposition (Búrques et al., 1999), the litter traps were emptied and the leaves were dried and weighed at several occasions during the growing seasons. The total LAI was then calculated through the mass of the collected leaves, the SLA, and the litter-trap areas (Fassnacht et al., 1997). The

\begin{tabular}{|c|c|c|}
\hline Symbol & Definition & Reference \\
\hline$L$ & Half the total leaf surface area per unit ground area & Chen and Black, 1992 \\
\hline$L_{\mathrm{e}}$ & Effective LAI, i.e., the product of $L$ and a foliage clumping index & Black et al., 1991 \\
\hline$L_{\mathrm{G}}$ & $L$ estimated by correcting $L_{\mathrm{e}}$ for needle clumping in conifers; Equation (2) & Gower and Norman, 1991 \\
\hline$L_{\mathrm{C}}$ & $\begin{array}{l}L \text { estimated by correcting } L_{\mathrm{e}} \text { for needle clumping, tree-branch distribution, } \\
\text { and nonleafy material; Equation (3) }\end{array}$ & Chen, 1996 \\
\hline$L_{\mathrm{K}}$ & $\begin{array}{l}L \text { estimated by correcting } L_{\mathrm{e}} \text { for needle clumping, tree-branch distribution, } \\
\text { and nonleafy material; Equation (4) }\end{array}$ & Kucharik et al., 1998 \\
\hline$L_{\mathrm{M}}$ & $L$ estimated with allometric equations in conifers & $\begin{array}{l}\text { Marklund, 1988; } \\
\text { Lagergren and Lindroth, } 2002\end{array}$ \\
\hline
\end{tabular}

Table 3. Symbols used in the text for variables related to LAI.

\footnotetext{
${ }^{3}$ Using $35^{\circ}$ may introduce a bias, since the weighted average gap fraction over the view field of the LAI-2000 is not equal to that at the average view angle. The bias varies with canopy characteristics, the instrument weighting of the view angles, and the discrete approximation to Equation (1).
} 
result should be regarded as the maximum LAI value of the season, since the leaf mass was summed for the whole season.

\section{Vegetation indices}

Various vegetation indices were computed from the atmospherically corrected TM sensor data for testing against estimated in situ LAI (Table 5). In addition, multiple regressions were computed between all single wavelength bands and the LAI estimates. The bands to be included in the final relationships were selected according to a stepwise procedure where only a small number of statistically significant bands were retained (Berenson et al., 1983).

In the statistical testing, mostly linear relationships were analysed, but nonlinear models were also tested for a few of the best relationships in each category (coniferous, deciduous, etc.).

Table 4. Statistics for leaf litter collection plots L1-L6.

\begin{tabular}{|c|c|c|c|c|c|}
\hline & L1 & L2 & L4 & L5 & L6 \\
\hline Species & $\begin{array}{l}\text { Ash } \\
\quad \text { (Fraxinus excelsior) }\end{array}$ & $\begin{array}{l}\text { Oak } \\
\text { (Quercus robur) }\end{array}$ & $\begin{array}{l}\text { Birch } \\
\quad \text { (Betula pubescens) }\end{array}$ & $\begin{array}{l}\text { Beech } \\
\quad \text { (Fagus sylvatica })\end{array}$ & $\begin{array}{l}\text { Oak } \\
\text { (Quercus robur) }\end{array}$ \\
\hline Plot size $\left(\mathrm{m}^{2}\right)$ & 5000 & 7000 & 10000 & 10000 & 10000 \\
\hline Tree density (trees $\cdot \mathrm{ha}^{-1}$ ) & 725 & 417 & 322 & 88 & 244 \\
\hline Crown diameter $(\mathrm{m})$ & 4.35 & 3.94 & 3.36 & 11.61 & 6.75 \\
\hline Crown height (m) & 5.20 & 4.53 & 6.06 & 13.41 & 6.59 \\
\hline \multicolumn{6}{|c|}{ Specific leaf area $\left(\mathrm{SLA} ; \mathrm{mm}^{2} \cdot \mathrm{mg}^{-1}\right)$} \\
\hline Mean & 27.6 & 20.8 & 14.8 & 25.3 & 17.4 \\
\hline Standard deviation & 2.28 & 1.78 & 0.97 & 1.76 & 1.83 \\
\hline
\end{tabular}

Table 5. Summary of vegetation indices tested in the study.

\begin{tabular}{|c|c|c|}
\hline Index & Equation & Reference \\
\hline SR & $\frac{\mathrm{TM} 4}{\mathrm{TM} 3}$ & Jordan, 1969 \\
\hline NDVI & $\frac{\mathrm{TM} 4-\mathrm{TM} 3}{\mathrm{TM} 4+\mathrm{TM} 3}$ & Rouse et al., 1974 \\
\hline SAVI & $(1+L) \frac{\mathrm{TM} 4-\mathrm{TM} 3}{\mathrm{TM} 4+\mathrm{TM} 3+L} ; \quad L$ was set to 0.5 & Huete, 1988 \\
\hline OSAVI & $(1+L) \frac{\mathrm{TM} 4-\mathrm{TM} 3}{\mathrm{TM} 4-\mathrm{TM} 3+L} ; \quad L$ was set to 0.16 & Rondeaux et al., 1996 \\
\hline ARVI & $\frac{\mathrm{TM} 4-\mathrm{RB}}{\mathrm{TM} 4+\mathrm{RB}} ; \quad \mathrm{RB}=\mathrm{TM} 3-\gamma(\mathrm{TM} 1-\mathrm{TM} 3) ; \quad \gamma$ was set to 1.0 & Kaufman and Tanré, 1992 \\
\hline GEMI & $\eta(1-0.25 \eta)-\frac{\mathrm{TM} 3-0.125}{1-\mathrm{TM} 3} ; \quad \eta=\frac{2\left(\mathrm{TM} 4^{2}-\mathrm{TM} 3^{2}\right)+1.5 \mathrm{TM} 4+0.5 \mathrm{TM} 3}{\mathrm{TM} 4+\mathrm{TM} 3+0.5}$ & Pinty and Verstraete, 1992 \\
\hline $\mathrm{NDVI}_{4,7}$ & $\frac{\mathrm{TM} 4-\mathrm{TM} 7}{\mathrm{TM} 4+\mathrm{TM} 7}$ & $\begin{array}{l}\text { Modified VI3 index from } \\
\text { Kaufman and Remer, } 1994\end{array}$ \\
\hline $\mathrm{NDVI}_{\mathrm{c}}$ & $\begin{array}{l}\frac{\mathrm{TM} 4-\mathrm{TM} 3}{\mathrm{TM} 4+\mathrm{TM} 3}\left(1-\frac{\mathrm{TM} 5-\mathrm{TM} 5_{\min }}{\mathrm{TM} 5_{\max }-\mathrm{TM} 5_{\min }}\right) ; \mathrm{TM} 5_{\min } \text { and } \mathrm{TM} 5_{\max } \text { are MIR values } \\
\quad \text { for completely closed and open canopies, respectively }\end{array}$ & Nemani et al., 1993 \\
\hline RSR & $\frac{\mathrm{TM} 4}{\mathrm{TM} 3}\left(1-\frac{\mathrm{TM} 5-\mathrm{TM} 5_{\min }}{\mathrm{TM} 5_{\max }-\mathrm{TM} 5_{\min }}\right) ; \quad \mathrm{TM} 5_{\min }$ and $\mathrm{TM} 5_{\max }$ are defined as in $\mathrm{NDVI} \mathrm{c}_{\mathrm{c}}$ & Brown et al., 2000 \\
\hline MSI & $\frac{\mathrm{TM} 5}{\mathrm{TM} 4}$ & Vogelmann, 1990 \\
\hline
\end{tabular}


Table 6. Correlation matrices for LAI estimates.

\begin{tabular}{|c|c|c|c|}
\hline \multicolumn{4}{|c|}{ (A) All stands $(n=63)$} \\
\hline & $L_{\mathrm{G}}$ & $L_{C}$ & \\
\hline$L_{\mathrm{C}}$ & $\mathbf{0 . 3 8}$ & & \\
\hline$L_{\mathrm{K}}$ & 0.37 & 1 & \\
\hline \multicolumn{4}{|c|}{ (B) Coniferous stands $(n=17)$} \\
\hline & $L_{\mathrm{G}}$ & $L_{\mathrm{C}}$ & $L_{\mathrm{K}}$ \\
\hline$L_{\mathrm{C}}$ & -0.09 & & \\
\hline$L_{\mathrm{K}}$ & -0.10 & 1 & \\
\hline$L_{\mathrm{M}}$ & 0.4 & -0.46 & -0.46 \\
\hline \multicolumn{4}{|c|}{ (C) Deciduous stands $(n=40)$} \\
\hline & $L_{\mathrm{G}}$ & $L_{\mathrm{C}}$ & \\
\hline$L_{\mathrm{C}}$ & 0.57 & & \\
\hline$L_{\mathrm{K}}$ & 0.56 & 1 & \\
\hline
\end{tabular}

\section{Results}

\section{Relationships between different LAI estimates}

Correlation coefficients $(r)$ were computed for the relationships between the different estimates $L_{\mathrm{G}}, L_{\mathrm{C}}, L_{\mathrm{K}}$, and $L_{\mathrm{M}}$ (see Table 3 for explanation of symbols) for all stands and for coniferous and deciduous stands separately (Table 6). The two estimates $L_{\mathrm{C}}$ and $L_{\mathrm{K}}$ both depend on the estimation of the clumping factor $\Omega_{\mathrm{e}}$ using the method in Kucharik et al. (1999), and these estimates are strongly correlated with each other. The estimates $L_{\mathrm{G}}$ and $L_{\mathrm{M}}$ (the latter variable only exists for coniferous stands) are only weakly correlated with each other, and correlations with the estimates $L_{\mathrm{C}}$ and $L_{\mathrm{K}}$ are negative.

\section{Relationships between TM data and LAI estimates}

Tables 7-9 list correlation coefficients for the relationship between various estimates of LAI and single band reflectance and vegetation indices. Table 7 describes all plots (including the mixed plots of Table 2), whereas Table 8 is restricted to coniferous plots and Table 9 to deciduous plots. In all the tables the correlation patterns are similar for $L_{\mathrm{K}}$ and $L_{\mathrm{C}}$. This is due to the strong influence of the clumping factor $\Omega_{\mathrm{e}}$, computed in the same way for both estimates according to the method of Kucharik et al. (1999).

TM4, TM5, and TM7 are significantly correlated with the LAI estimates $L_{\mathrm{K}}$ and $L_{\mathrm{C}}$ for all stands (Table 7). Of the 10 vegetation indices analysed, seven are significantly related to $L_{\mathrm{K}}$ and $L_{\mathrm{C}}$. GEMI is the index with the strongest relationship $(r=-0.44)$. Correlations with $L_{\mathrm{G}}$ are generally stronger than those with $L_{\mathrm{K}}$ and $L_{\mathrm{C}}$. A plot of TM4 versus $L_{\mathrm{G}}$ displays clearly separated clusters for coniferous and deciduous stands (Figure 1). The strongest correlation is with TM7 (Figure 2);
Table 7. Correlation coefficients $(r)$ and root mean square errors $(s)$ for linear relationships between $L_{\mathrm{K}}, L_{\mathrm{C}}, L_{\mathrm{G}}$, and Landsat TM reflectances and vegetation indices for all plots.

\begin{tabular}{|c|c|c|c|c|c|c|}
\hline \multirow[b]{2}{*}{ Band or index } & \multicolumn{2}{|l|}{$\underline{L_{\mathrm{K}}}$} & \multicolumn{2}{|l|}{$\underline{\mathrm{L}_{\mathrm{C}}}$} & \multicolumn{2}{|l|}{$\underline{\mathrm{L}_{\mathrm{G}}}$} \\
\hline & $r$ & $s$ & $r$ & $s$ & $r$ & $s$ \\
\hline TM1 & -0.12 & 6.1 & -0.13 & 4.6 & -0.46 & 1.9 \\
\hline TM2 & -0.22 & 6.0 & -0.24 & 4.5 & -0.48 & 1.8 \\
\hline TM3 & -0.10 & 6.2 & -0.10 & 4.6 & -0.51 & 1.8 \\
\hline TM4 & -0.43 & 5.6 & -0.44 & 4.2 & $-\mathbf{0 . 3 0}$ & 2.0 \\
\hline TM5 & -0.34 & 5.8 & -0.35 & 4.4 & -0.61 & 1.7 \\
\hline TM7 & -0.25 & 6.0 & -0.26 & 4.2 & -0.66 & 1.6 \\
\hline Multiple regression & $-\mathbf{0 . 4 3}^{a}$ & 5.6 & $0.44^{a}$ & 4.2 & $-0.66^{b}$ & 1.6 \\
\hline SR & -0.26 & 6.0 & -0.27 & 4.5 & 0.01 & 2.1 \\
\hline NDVI & -0.25 & 6.0 & -0.25 & 4.5 & 0.06 & 2.1 \\
\hline SAVI & -0.43 & 5.6 & -0.43 & 4.2 & -0.25 & 2.0 \\
\hline OSAVI & -0.43 & 5.6 & -0.44 & 4.1 & -0.30 & 2.0 \\
\hline ARVI & -0.21 & 6.0 & -0.21 & 4.6 & 0.12 & 2.1 \\
\hline GEMI & -0.44 & 5.6 & -0.44 & 4.2 & $-\mathbf{0 . 3 0}$ & 2.0 \\
\hline $\mathrm{NDVI}_{4.7}$ & -0.16 & 6.1 & -0.16 & 4.6 & 0.31 & 2.0 \\
\hline $\mathrm{NDVI}_{\mathrm{c}}$ & 0.35 & 5.8 & 0.36 & 4.3 & 0.62 & 1.6 \\
\hline RSR & 0.33 & 5.8 & 0.34 & 4.4 & 0.61 & 1.7 \\
\hline MSI & 0.14 & 6.1 & 0.14 & 4.6 & -0.44 & 1.9 \\
\hline$n^{c}$ & 63 & & 64 & & 67 & \\
\hline
\end{tabular}

Note: Correlation coefficients in bold are statistically significant $(p=0.05)$. ${ }^{a}$ TM4.

${ }^{b}$ TM7.

${ }^{c}$ Sample sizes vary due to lack of data required for the corrections in some plots.

however, it is also evident for TM7 that deciduous and coniferous species form different clusters. Of the vegetation indices, SR and NDVI perform poorly, whereas $\mathrm{NDVI}_{\mathrm{c}}$ and RSR are the best. A plot of $\mathrm{NDVI}_{\mathrm{c}}$ versus $L_{\mathrm{G}}$ is shown in Figure 3, and it displays different clusters for coniferous and deciduous species.

When restricting the analysis to coniferous stands (Table 8), no statistically significant correlation coefficients are observed for $L_{\mathrm{K}}$ and $L_{\mathrm{C}}$. The visible bands (TM1-TM3), however, are significantly related to $L_{\mathrm{M}}$, and all bands except TM4 are significantly related to $L_{\mathrm{G}}$. The strongest single band relationships are with TM5 (Figure 4) and TM7. A logarithmic relationship improves the correlation slightly (not significantly) compared with the linear coefficient given in Table 8. Seven vegetation indices are significantly correlated to $L_{\mathrm{G}}$, and these consistently give the highest correlations for $L_{\mathrm{M}}$ as well. The strongest correlated vegetation index is MSI (Figure 5), and the strongest overall correlation coefficient is generated with a multiple regression between $L_{\mathrm{G}}$ and TM4 and TM5 (Figure 6).

In deciduous forest stands (Table 9), TM3 and TM4 are the only single bands that express significant relationships with $L_{\mathrm{K}}$ and $L_{\mathrm{C}}$. Eight out of 10 indices are significantly correlated, and the strongest correlation is observed with the simple index SR. The overall strongest relationship is generated with a multiple regression of TM1, TM3, and TM4 (Figure 7).

Relationships between TM data and the LAI estimates $L_{\mathrm{C}}$ and $L_{\mathrm{K}}$ are fairly similar to those with $L_{\mathrm{G}}$ with respect to positive and negative relationships and the number of 
Table 8. Correlation coefficients $(r)$ and root mean square errors $(s)$ for linear relationships between $L_{\mathrm{K}}, L_{\mathrm{C}}, L_{\mathrm{G}}$, $L_{\mathrm{M}}$, and Landsat TM reflectances and vegetation indices for the coniferous plots.

\begin{tabular}{|c|c|c|c|c|c|c|c|c|}
\hline \multirow[b]{2}{*}{ Band or index } & \multicolumn{2}{|l|}{$L_{\mathrm{K}}$} & \multicolumn{2}{|l|}{$\underline{\mathrm{L}_{\mathrm{C}}}$} & \multicolumn{2}{|l|}{$\underline{\mathrm{L}_{\mathrm{G}}}$} & \multicolumn{2}{|l|}{$L_{\mathrm{M}}$} \\
\hline & $r$ & $s$ & $r$ & $s$ & $r$ & $s$ & $r$ & $s$ \\
\hline TM1 & 0.06 & 8.86 & 0.05 & 6.67 & -0.63 & 1.96 & -0.46 & 1.80 \\
\hline TM2 & 0.06 & 8.86 & 0.05 & 6.67 & -0.62 & 1.99 & -0.49 & 1.77 \\
\hline TM3 & 0.02 & 8.88 & 0.01 & 6.67 & -0.74 & 1.71 & -0.49 & 1.77 \\
\hline TM4 & 0.32 & 8.42 & 0.32 & 6.33 & -0.12 & 2.53 & -0.19 & 1.99 \\
\hline TM5 & 0.21 & 8.68 & 0.20 & 6.54 & -0.80 & 1.53 & -0.41 & 1.85 \\
\hline TM7 & 0.10 & 8.84 & 0.09 & 6.65 & -0.80 & 1.53 & -0.44 & 1.82 \\
\hline Multiple regression & - & - & - & - & $0.89^{a}$ & 1.18 & $0.49^{b}$ & 1.77 \\
\hline SR & 0.21 & 8.71 & 0.20 & 6.53 & 0.60 & 2.02 & 0.40 & 1.85 \\
\hline NDVI & 0.18 & 8.75 & 0.18 & 6.57 & 0.71 & 1.79 & 0.42 & 1.84 \\
\hline SAVI & 0.32 & 8.43 & 0.32 & 6.33 & 0.33 & 2.40 & 0.11 & 2.01 \\
\hline OSAVI & 0.32 & 8.42 & 0.32 & 6.32 & 0.17 & 2.51 & -0.00 & 2.03 \\
\hline ARVI & 0.18 & 8.74 & 0.18 & 6.56 & 0.74 & 1.72 & 0.42 & 1.84 \\
\hline GEMI & 0.31 & 8.45 & 0.31 & 6.35 & 0.07 & 2.54 & -0.06 & 2.02 \\
\hline $\mathrm{NDVI}_{4.7}$ & 0.06 & 8.87 & 0.07 & 6.66 & 0.78 & 1.58 & 0.42 & 1.88 \\
\hline $\mathrm{NDVI}_{\mathrm{c}}$ & -0.15 & 8.78 & -0.14 & 6.61 & 0.80 & 1.51 & 0.43 & 1.83 \\
\hline RSR & -0.01 & 8.82 & -0.00 & 6.67 & 0.75 & 1.68 & 0.44 & 1.81 \\
\hline MSI & 0.02 & 8.81 & 0.01 & 6.78 & -0.86 & 1.28 & -0.36 & 1.90 \\
\hline$n$ & 17 & & 17 & & 19 & & 18 & \\
\hline
\end{tabular}

Note: Correlation coefficients in bold are statistically significant $(p=0.05)$.

${ }^{a}$ TM4, TM5.

${ }^{b} \mathrm{TM} 3$.

Table 9. Correlation coefficients $(r)$ and root mean square errors $(s)$ for linear relationships between $L_{\mathrm{K}}, L_{\mathrm{C}}, L_{\mathrm{G}}$, and Landsat TM reflectances and vegetation indices for the deciduous plots.

\begin{tabular}{|c|c|c|c|c|c|c|}
\hline \multirow[b]{2}{*}{ Band or index } & \multicolumn{2}{|l|}{$L_{\mathrm{K}}$} & \multicolumn{2}{|l|}{$\mathrm{L}_{\mathrm{C}}$} & \multicolumn{2}{|l|}{$\underline{\mathrm{L}_{\mathrm{G}}}$} \\
\hline & $r$ & $s$ & $r$ & $s$ & $r$ & $s$ \\
\hline TM1 & -0.05 & 1.99 & -0.06 & 1.51 & -0.09 & 1.31 \\
\hline TM2 & -0.12 & 1.98 & -0.11 & 1.50 & -0.04 & 1.32 \\
\hline TM3 & -0.32 & 1.88 & -0.32 & 1.43 & -0.35 & 1.24 \\
\hline TM4 & 0.37 & 1.86 & 0.36 & 1.41 & 0.54 & 1.11 \\
\hline TM5 & -0.14 & 1.97 & -0.12 & 1.50 & -0.16 & 1.30 \\
\hline TM7 & -0.10 & 1.98 & -0.10 & 1.50 & -0.18 & 1.30 \\
\hline Multiple regression & $0.65^{a}$ & 1.56 & $0.64^{a}$ & 1.19 & $0.72^{b}$ & 0.94 \\
\hline SR & 0.51 & 1.71 & 0.50 & 1.31 & 0.66 & 0.98 \\
\hline NDVI & 0.50 & 1.72 & 0.49 & 1.32 & 0.62 & 1.03 \\
\hline SAVI & 0.42 & 1.81 & 0.41 & 1.34 & 0.58 & 1.07 \\
\hline OSAVI & 0.38 & 1.84 & 0.38 & 1.40 & 0.53 & 1.12 \\
\hline ARVI & 0.48 & 1.65 & 0.55 & 1.26 & 0.64 & 1.02 \\
\hline GEMI & 0.39 & 1.83 & 0.38 & 1.40 & 0.55 & 1.10 \\
\hline $\mathrm{NDVI}_{4.7}$ & 0.41 & 1.81 & 0.41 & 1.38 & 0.60 & 1.05 \\
\hline $\mathrm{NDVI}_{\mathrm{c}}$ & -0.10 & 1.98 & -0.08 & 1.51 & -0.12 & 1.31 \\
\hline RSR & 0.09 & 1.98 & 0.10 & 1.50 & 0.10 & 1.31 \\
\hline MSI & -0.41 & 1.81 & -0.42 & 1.37 & -0.62 & 1.22 \\
\hline$n$ & 40 & & 41 & & 42 & \\
\hline
\end{tabular}

Note: Correlation coefficients in bold are statistically significant $(p=$ $0.05)$.

${ }^{a} \mathrm{TM} 1, \mathrm{TM} 3, \mathrm{TM} 4$.

${ }^{b} \mathrm{TM} 3, \mathrm{TM} 4, \mathrm{TM} 5$.

statistically significant correlation coefficients for deciduous stands. However, the correlation coefficients are consistently larger for $L_{\mathrm{G}}$ than for the other estimates. Among the single bands, TM4 is the band that is best related to $L_{\mathrm{G}}$, whereas SR is

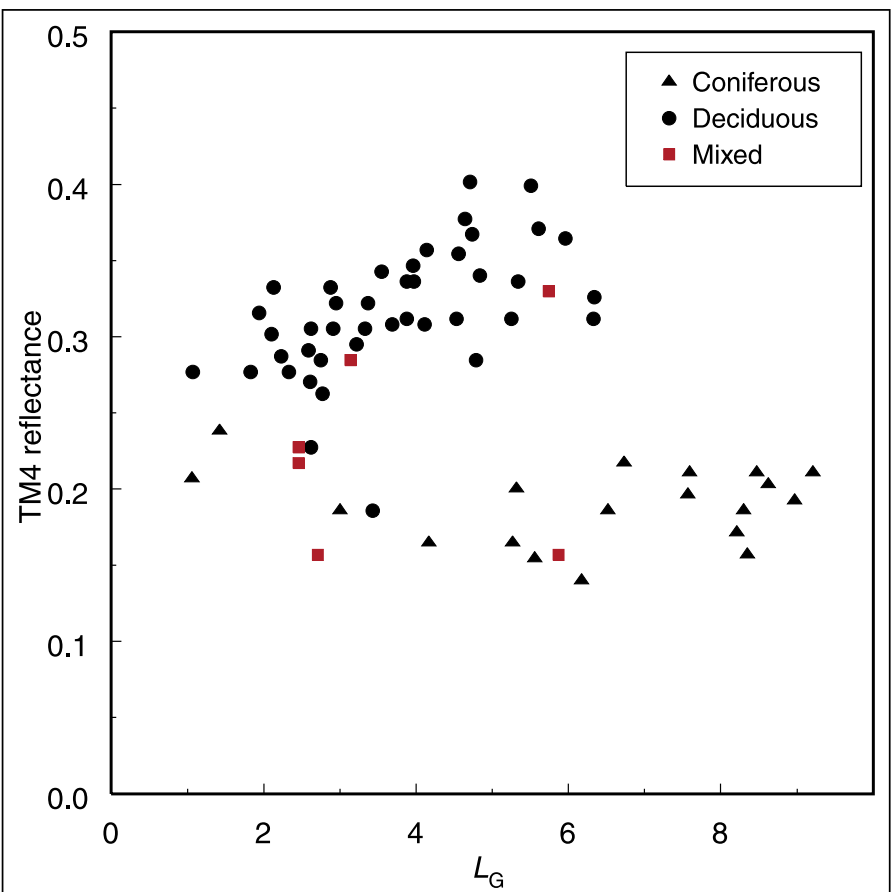

Figure 1. Relationship between $L_{\mathrm{G}}$ and TM4 reflectance for all 67 plots.

the vegetation index that is best related to $L_{\mathrm{G}}$ (Figure 8). The strongest overall relationship for deciduous stands is observed when $L_{\mathrm{G}}$ is predicted with a regression equation with TM3, TM4, and TM5 (Figure 9).

Six of the stands in the study belong to the class "mixed", i.e., they contain both broadleaf and coniferous trees. No 


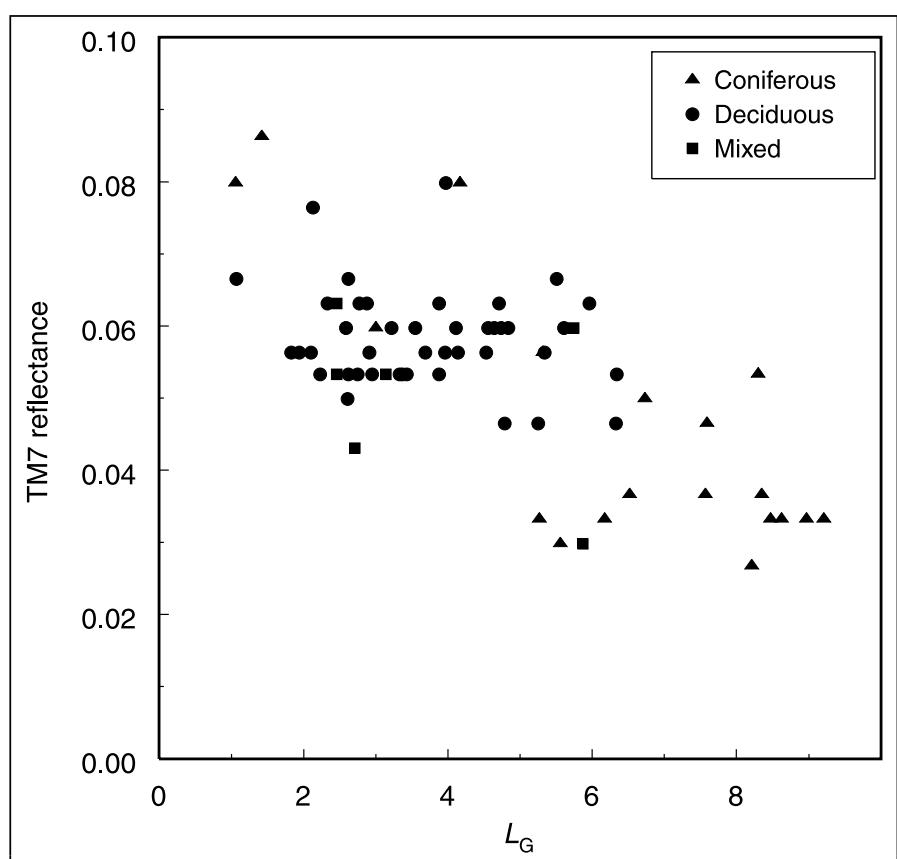

Figure 2. Relationship between $L_{\mathrm{G}}$ and TM7 reflectance for all 67 plots.

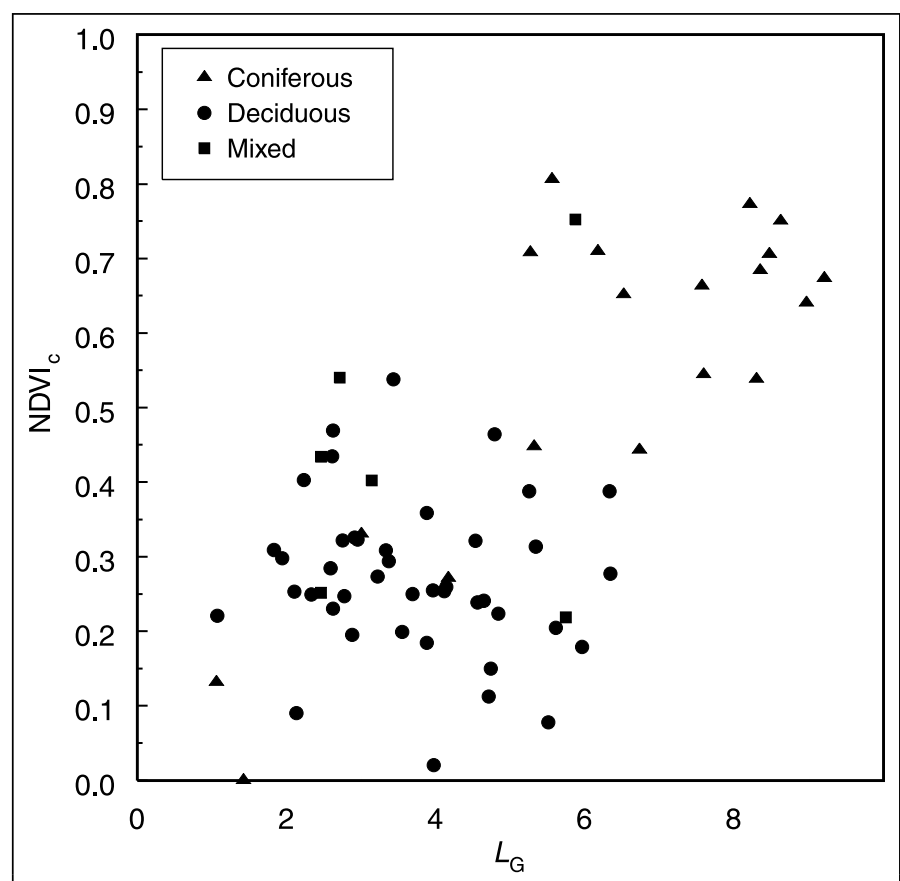

Figure 3. Relationship between $L_{\mathrm{G}}$ and $\mathrm{NDVI}_{\mathrm{c}}$ for all 67 plots.

separate statistics have been presented for these few stands. When studying the proportions of broadleaf and coniferous trees in the stands, however, it is clear that these proportions determine to which cluster the stands belong. A mixed stand with a high proportion of coniferous trees is located in the lower cluster of Figure 1, whereas a mixed stand with high proportion of deciduous trees is located in the upper cluster of Figure 1.

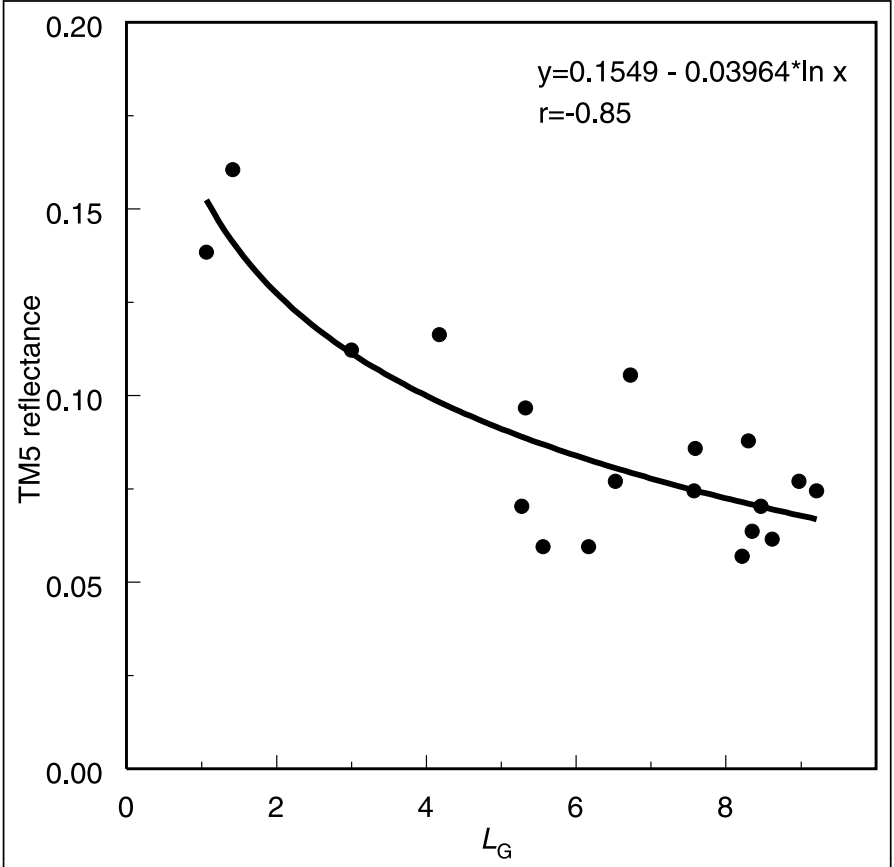

Figure 4. Relationship between $L_{\mathrm{G}}$ and TM5 reflectance for the coniferous plots $(n=19)$.

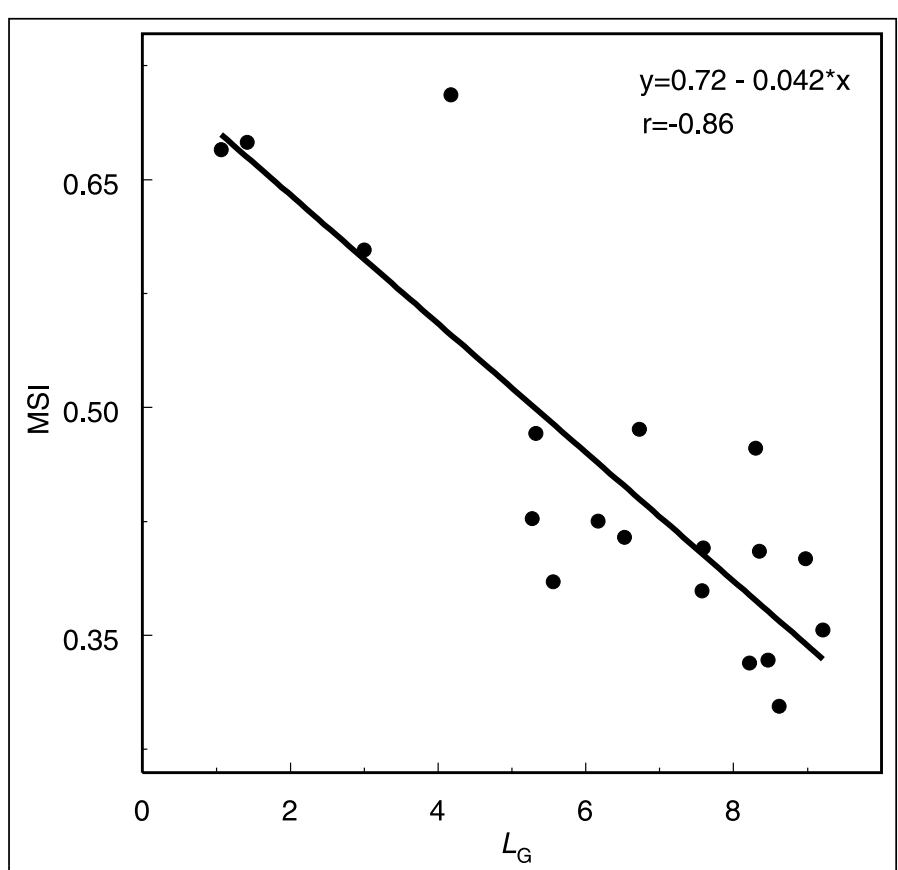

Figure 5. Relationship between $L_{\mathrm{G}}$ and MSI for the coniferous plots $(n=19)$.

\section{Litter-trap data}

Results from the litter-trap analysis are summarized in Figure 10. There is good correspondence between litter-trap LAI $\left(L_{\text {litter }}\right)$ for both 2000 and $2001(r=0.95)$, and generally there is a tendency for LAI to increase from 2000 to 2001, except in one (L1) of the five plots. 


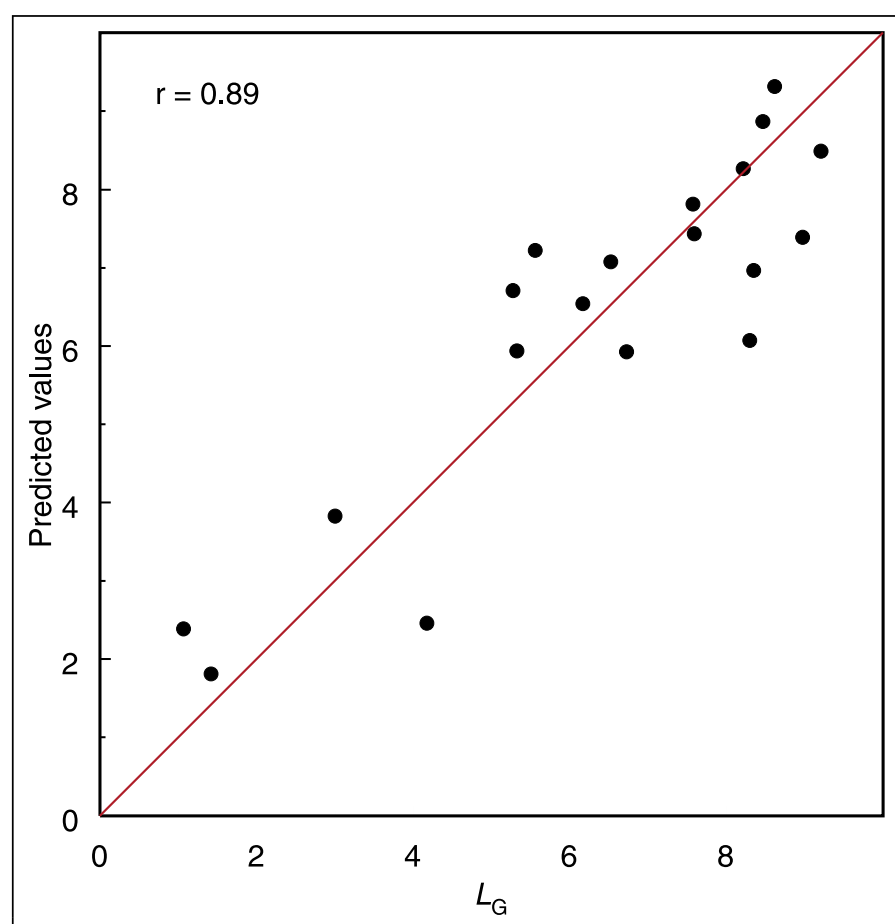

Figure 6. Relationship between $L_{\mathrm{G}}$ and predicted values for the regression $y=5.5+47.1$ (TM4) -92.5 (TM5) for the coniferous plots $(n=19)$.

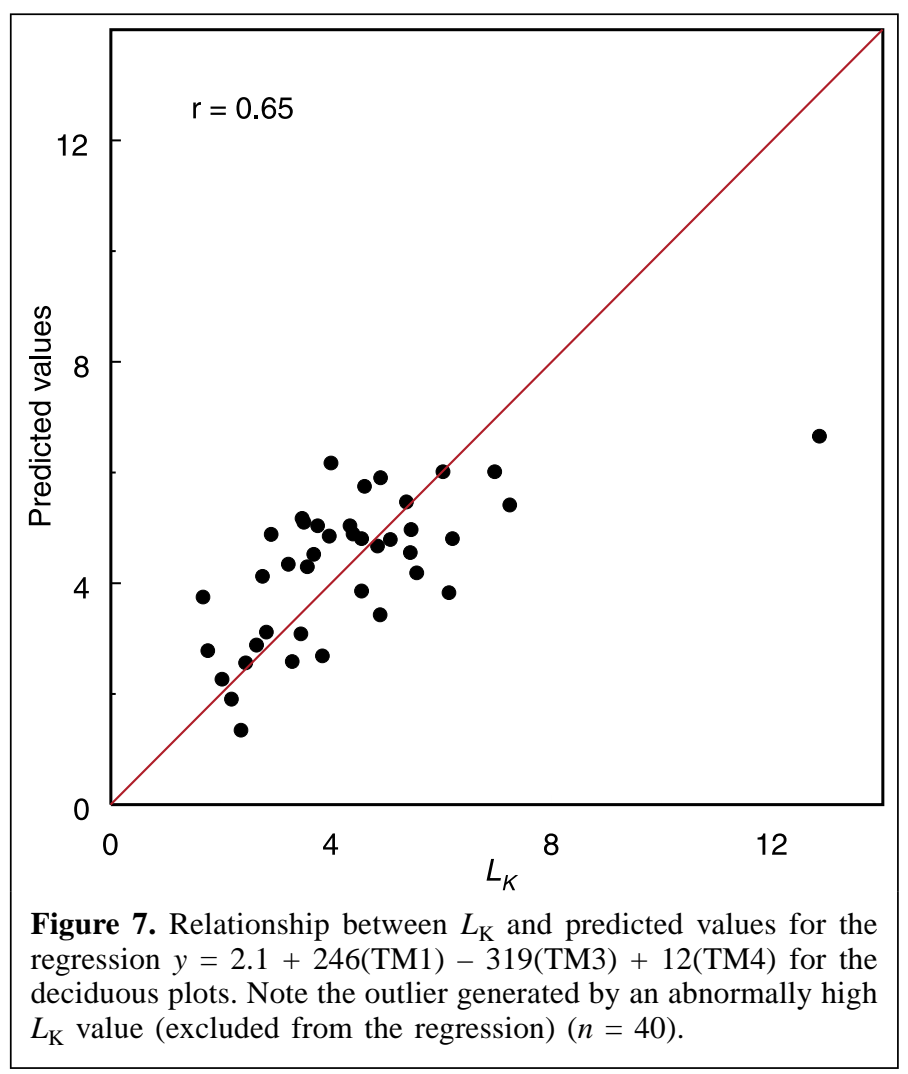

Observed litter-trap LAI has been compared with the optical LAI estimates in Figure 11. In three stands, $L_{\mathrm{G}}$ is lower than $L_{\text {litter }}$, and in two stands it is higher. $L_{\mathrm{K}}$ and $L_{\mathrm{C}}$ are lower than

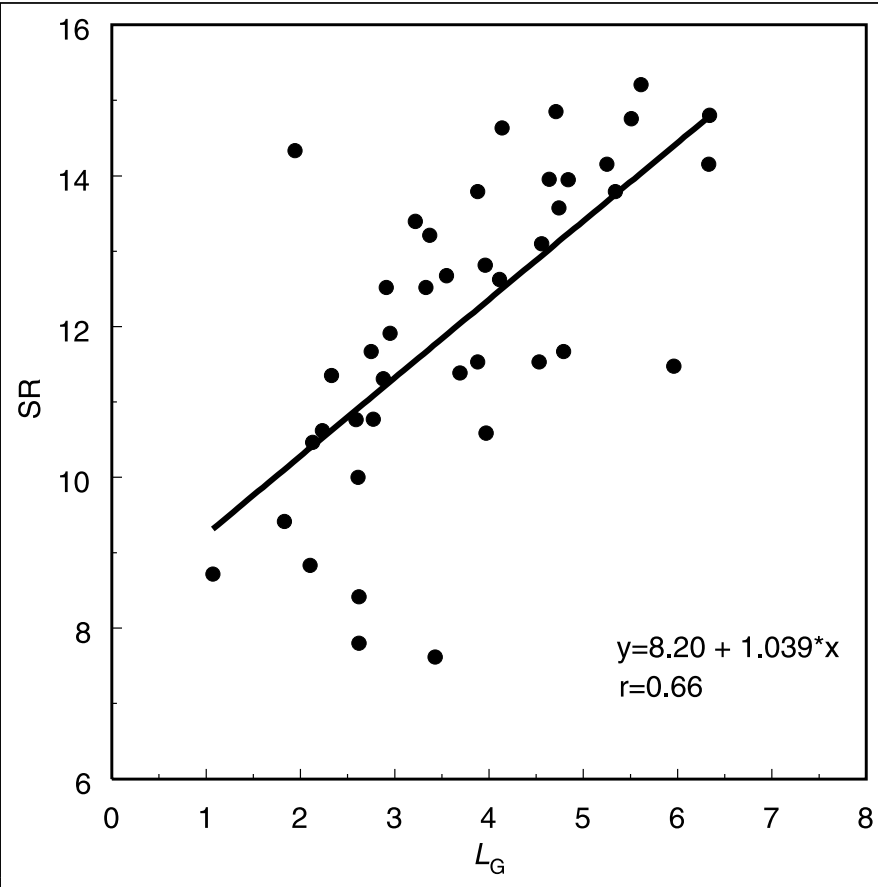

Figure 8. Relationship between $L_{\mathrm{G}}$ and SR for the deciduous plots $(n=42)$.

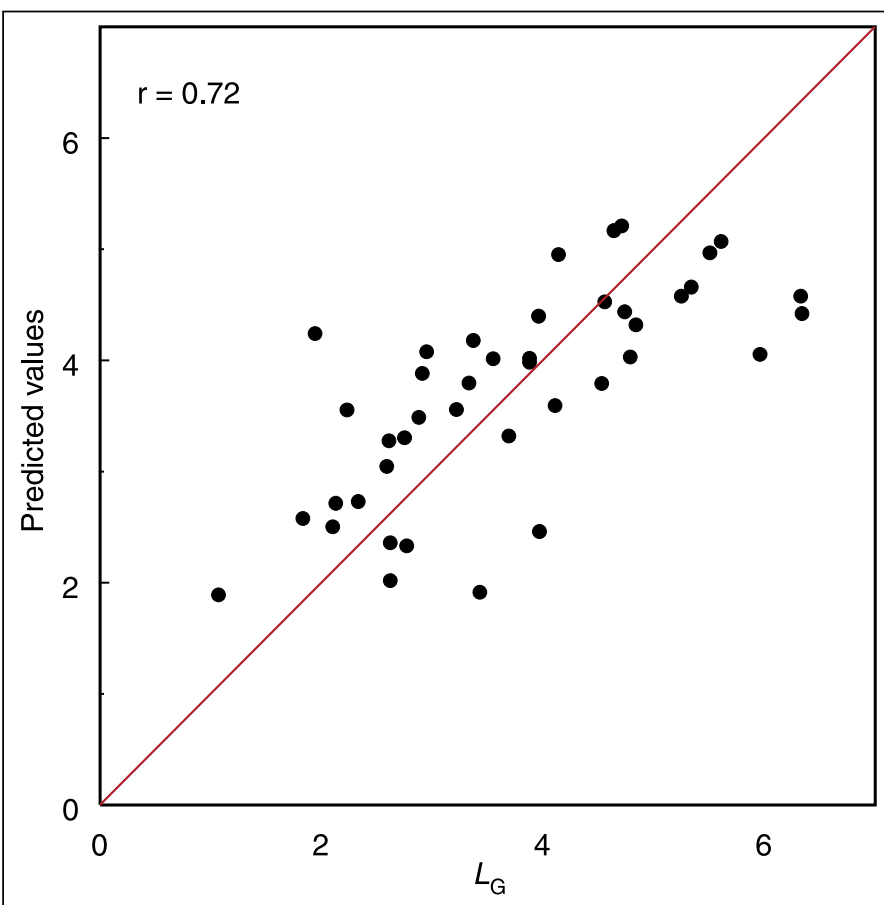

Figure 9. Relationship between $L_{\mathrm{G}}$ and predicted values for the regression $y=2.8-102(\mathrm{TM} 3)+28(\mathrm{TM} 4)-41(\mathrm{TM} 5)$ for the deciduous plots $(n=42)$.

$L_{\text {litter }}$ in two stands and higher in three stands. In stand L4, which is sparse birch, $L_{\mathrm{K}}$ and $L_{\mathrm{C}}$ are clearly overestimated. The root mean squared (RMS) difference is 0.5 for $L_{\mathrm{G}}, 2.5$ for $L_{\mathrm{K}}$, and 2.0 for $L_{\mathrm{C}}$ (the latter two values exclude stand L4). 


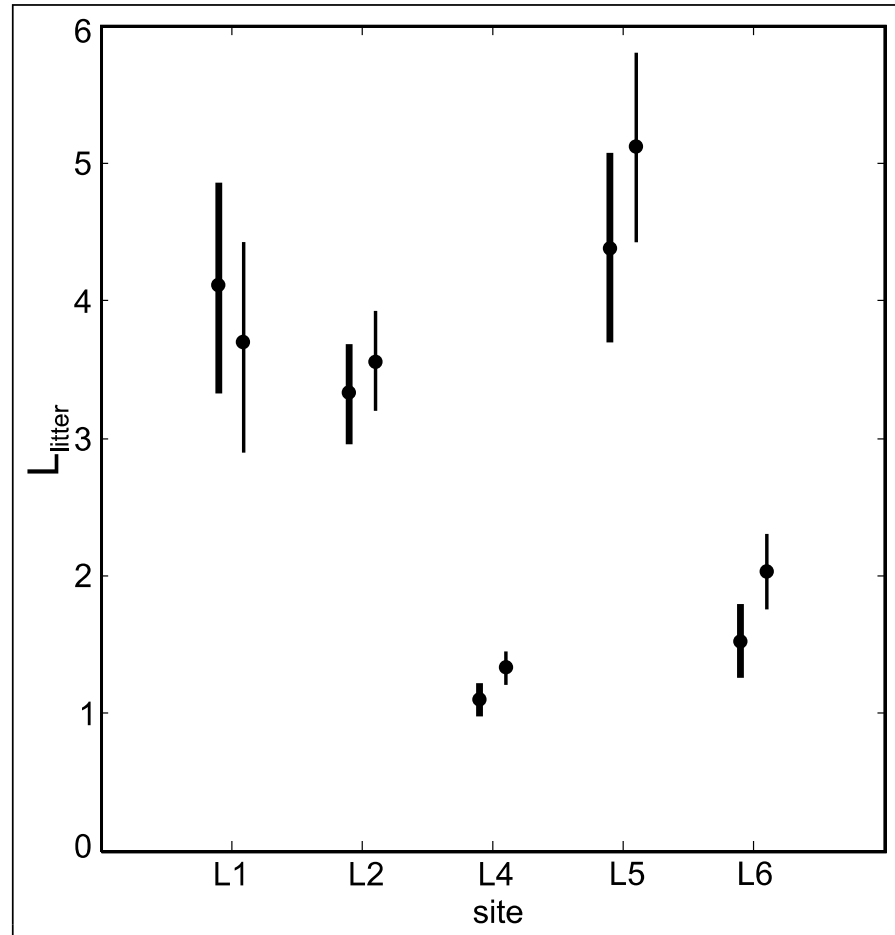

Figure 10. Means and 95\% confidence intervals for leaf litter collected during 2000 (thick lines) and 2001 (thin lines).

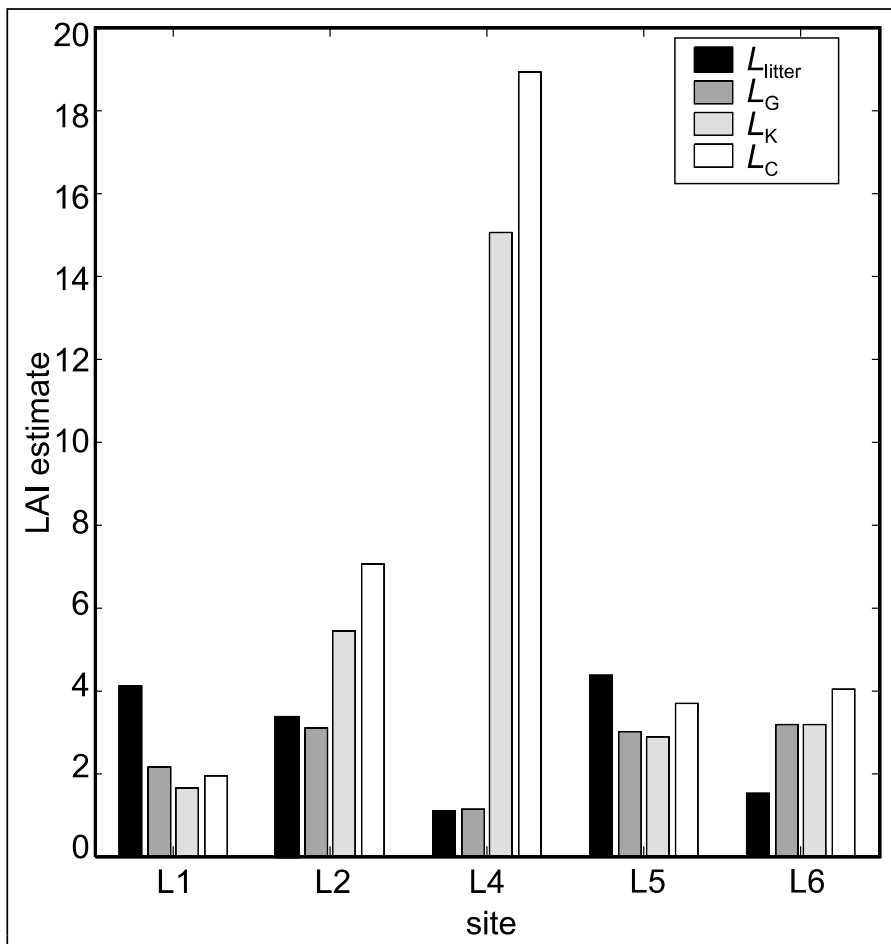

Figure 11. Comparison of litter-fall LAI and optical LAI estimates for 2000. See Table 3 for an explanation of the four different LAI symbols.

\section{Discussion}

This study has investigated the use of Landsat TM for estimating LAI. The presented results should be viewed with the limitations of such an empirical study in mind: the sample size is limited due to practical considerations, and the relationships have only been tested on a single Landsat TM scene. To assess the validity of the results it is thus necessary to compare these results with those obtained by other authors.

In coniferous stands the visible bands TM1-TM3 are significantly related to $L_{\mathrm{G}}$ and $L_{\mathrm{M}}$, with a strong relationship observed for TM3 (Table 8). This result is corroborated by Eklundh et al. (2001), Peterson et al. (1987), and Spanner et al. (1990a). On the other hand, Fassnacht et al. (1997) observed poor performance of the red band and identified the green band as the most important in the visible range. In the NIR band, statistically significant relationships are not obtained for the coniferous plots. This is in agreement with reflectance modelling results by Eklundh et al. and is also confirmed by Peterson et al. and Spanner et al. According to Peterson et al., the poor correlation may be explained by the structure and the position of the conifer needles. Spanner et al. observed a strong relationship in closed stands, but a weak relationship in open stands and argue that canopy closure is an important factor. Strong relationships are obtained between $L_{\mathrm{G}}$ and the MIR bands (TM5 and TM7) for coniferous plots, which is in agreement with Nilsson et al. (1999) and Eklundh et al. Several vegetation indices are strongly correlated with $L_{\mathrm{G}}$ in coniferous plots (Table 8). An exception is SAVI, which was found useful for estimating LAI by some other authors (Turner et al., 1999; Broge and Leblanc, 2001; Elvidge and Zhikang, 1995). Including an MIR band, by modifying NDVI to $\mathrm{NDVI}_{4,7}$, improves the relationship somewhat (not significantly) in coniferous plots. This confirms the results by Boyd et al. (2000), who showed that the relationship between LAI and the VI3 vegetation index was stronger than that between LAI and NDVI. Somewhat stronger relationships are also found when including an MIR scaling to the SR and to the NDVI, which is in agreement with the results of Brown et al. (2000), Chen et al. (2002), and Nemani et al. (1993). Among the vegetation indices, the highest correlation coefficient is generated with the MSI, which explains about $75 \%$ of the variation in $L_{\mathrm{G}}$ (Figure 5). Overall, the strongest relationship for conifers, explaining $80 \%$ of the variation in $L_{\mathrm{G}}$, is obtained when $L_{\mathrm{G}}$ is predicted as a function of TM4 and TM5 (Figure 6). It should be noted that the MIR channels are sensitive to surface moisture variation that may affect relationships (Brown et al., 2000). This effect was not tested in our study.

In deciduous stands, only the single bands TM3 and TM4 are statistically related to the LAI estimates, whereas eight of the 10 vegetation indices tested are statistically significant (Table 9). Blackburn (1999) found only weak positive relationships between visible wavelength reflectance and broadleaf LAI and concluded that, due to variations in leaf senescence, deciduous LAI may not be related to chlorophyll concentration per unit ground area and therefore may not be 
related to visible-band reflectance. At the Landsat acquisition date of our study (June 10) there may be certain phenological differences among the dominant deciduous tree species, since the leaves may not all be fully developed. The strongest relationships among the vegetation indices are observed for SR and MSI in deciduous stands, the former explaining $44 \%$ of the variation in $L_{\mathrm{G}}$ (Figure 8). The RSR performs poorly, which is contrary to observations by Chen et al. (2002), who found that RSR explained $62 \%$ of the variation in LAI. Overall, the strongest relationships for deciduous stands are obtained when $L_{\mathrm{K}}$ and $L_{\mathrm{C}}$ are predicted as a function of TM1, TM3, and TM4 (explaining $42 \%$ of the variation) and when $L_{\mathrm{G}}$ is predicted as a function of TM3, TM4, and TM5 (explaining 51\% of the variation; Figure 9).

In our study area, the level of explanation of the variation of $L_{\mathrm{G}}$ is about $30 \%$ higher for coniferous stands than for deciduous stands. Chen et al. (2002) found a similar difference in the estimation of actual LAI of about $10 \%$. There are several possible causes of the weaker relationships in deciduous stands. First, there is a basis for suspecting that the amount and type of ground vegetation in deciduous stands affect the relationships more than in coniferous stands, since ground vegetation is generally very sparse in coniferous stands in southern Sweden but may be abundant in deciduous stands. A second explanation may be related to the fact that the coniferous stands mostly consist of a single species (P. abies), whereas the deciduous stands consist of several species (F. sylvatica, $Q$. robur, Betula spp., $F$. excelsior, etc.), all with individual anatomy and biochemical leaf composition. Variations in pigment concentration per unit leaf area and differences in internal structure would result in differing light-scattering abilities. The coniferous stands are less affected by such differences. As pointed out by Blackburn (1999), spectral vegetation indices are likely to have restricted use for estimation of canopy LAI when the leaves have differing chlorophyll concentrations per unit leaf area. Third, there may be a difference in the level at which reflectance saturates between deciduous and coniferous species. Chen et al. found that multiple scattering increases rapidly with increasing LAI in deciduous species, causing saturation already at low levels, LAI values of about $2-3$. Since most mature deciduous forests have LAI values above 2, satellite remote sensing of these forests would clearly be limited. Our data have few observations below an LAI value of 2 , and no conclusions regarding any saturation effect can be drawn.

The correlation coefficients are lower overall when all plots are analysed together than when separating between coniferous and deciduous plots (Table 7). Some authors (Brown et al., 2000; Chen et al., 2002) have found that the RSR index may serve to unify mixed forest species, suggesting that LAI estimations may not require cover-type stratifications. In our study, RSR and NDVI $I_{\mathrm{c}}$ are highly correlated with $L_{\mathrm{G}}$, whereas SR and NDVI are not correlated with $L_{\mathrm{G}}$ at all. This supports the hypothesis that inclusion of an MIR band may have a unifying effect on samples from mixed stands. Nevertheless, the clear clustering of data according to tree type (Figure 3) suggests that a better strategy in our study area is to separate between coniferous and deciduous stands. This argument is strengthened by the fact that mixed stands fall in different clusters depending on the proportions of deciduous and coniferous trees.

There is good correspondence between litter-trap LAI for the two consecutive years, even though the number of traps was increased by $50-100 \%$ the second year, which supports the validity of the litter-trap estimates (Figure 10). The slight increase observed in four of the stands is expected because of the tree growth in the stands. There is only weak correspondence between litter-trap LAI and the optical measurements, and the conversion of $L_{\mathrm{G}}$ into $L_{\mathrm{K}}$ and $L_{\mathrm{C}}$ yields very large outliers in one of the plots (Figure 10). The RMS difference between litter-fall LAI and optical measurements is smaller for $L_{\mathrm{G}}$ than for $L_{\mathrm{K}}$ and $L_{\mathrm{C}}$. Considering the low number of litter-trap stands, covering a limited range in LAI, these results must be interpreted with caution.

In most cases the relationship with Landsat TM data is stronger for the simple estimate $L_{\mathrm{G}}$ than for $L_{\mathrm{K}}$ and $L_{\mathrm{C}}$. Several outliers of improbable $L_{\mathrm{K}}$ and $L_{\mathrm{C}}$ values affect the relationships with reflectance data. In deciduous plots, the number and size of outliers are lower, and the correspondence with $L_{\mathrm{G}}$ is better. Furthermore, in coniferous stands relationships between TM data and the allometric estimate $L_{\mathrm{M}}$ are more similar to relationships between TM data and $L_{\mathrm{G}}$ than to those between TM data and $L_{\mathrm{K}}$ or $L_{\mathrm{C}}$ (Table 8). There is only weak correlation (not significant) between $L_{\mathrm{M}}$ and $L_{\mathrm{G}}$, and the negative correlations between $L_{\mathrm{M}}$ and $L_{\mathrm{K}}$ or $L_{\mathrm{C}}$ are counterintuitive (Table 6). Correlation coefficients for the relationships between TM data and $L_{\mathrm{M}}$ are generally low, and these relationships are most likely influenced by errors due to sitespecific divergence from the general empirical relationships used (Gower et al., 1999).

The generally low correlations observed with $L_{\mathrm{K}}$ and $L_{\mathrm{C}}$ and the unrealistic LAI values in litter-trap plot L4 appear to be related to an overestimation of the clumping effect in the simplified procedure of Kucharik et al. (1999). The method is general in nature, but it contains several empirical calibrations that may not be well suited to our study area. Although relationships between Landsat TM data and $L_{\mathrm{G}}$ are better than those with $L_{\mathrm{K}}$ and $L_{\mathrm{C}}$, it must be emphasised that $L_{\mathrm{G}}$ only consists of a simple correction for needle clumping in conifers and is equal to $L_{\mathrm{e}}$ in deciduous plots.

Several methods for calculating LAI from light transmission measurements have been tested in the study. Although LAI2000 estimates of light transmission are comparatively easy to carry out, the ensuing estimation of LAI is problematic due to difficulties in measuring reliable in situ values required for the conversion. The low correlations obtained between the different estimates (Table 6) show that the sensitivity of the estimates to different conversion factors is very high, particularly to the clumping factor $\Omega_{\mathrm{e}}$.

The observed relationships between Landsat TM and $L_{\mathrm{G}}$ explain close to $80 \%$ of the variation in coniferous plots and close to $50 \%$ of the variation in deciduous plots. However, the 
degree to which true LAI can be estimated with Landsat TM also depends on the effect of branch- and tree-level clumping in the stands. Thus, the results of the study allow for two alternative interpretations: $(i)$ TM data are well correlated with $L_{\mathrm{G}}$ and, since $L_{\mathrm{G}}$ is a parameter related to LAI, there is a strong potential of Landsat TM data for mapping LAI; or (ii) although TM data and $L_{\mathrm{G}}$ are well correlated, $L_{\mathrm{G}}$ is not adequately corrected for clumping, and the good relationships observed may be due to some factor other than LAI that affects stand reflectances. To test these interpretations, measurements of gap distribution to determine the clumping effect would be needed. Examples of other important issues that need to be addressed in future studies are the influence of the understorey vegetation, saturation of the LAI-reflectance relationships, robustness to surface moisture status, and species-specific variations. Data on these factors will allow for more confidence in establishing the true relationships between LAI and satellite reflectance.

\section{Summary and conclusions}

LAI is an important structural variable in biogeochemical and hydrological modelling, and remote sensing may be a useful tool for its estimation over large areas. However, it is important to know the fidelity with which we can make the estimates. In this study we have analysed Landsat TM $30 \times$ $30 \mathrm{~m}$ resolution data over forest areas in southern Sweden, with a mixture of deciduous and coniferous species. We have tested parameters that are related to LAI and their relation with satellite-derived reflectances. The results can be summarized as follows:

(1) Branch- and tree-level clumping strongly affects optical field estimates of LAI. Calculations of clumping factors depend on values that are difficult to estimate in situ.

(2) Optical field estimates of LAI are only weakly correlated with estimates based on allometric relationships in coniferous stands (not tested for deciduous species).

(3) Significant relationships are observed between Landsat TM reflectances and parameters that are related to LAI.

(4) Correlations between estimated LAI and Landsat TM reflectances are increased when separating coniferous and deciduous stands, compared with analysing the two forest types together.

(5) The relationship between Landsat TM data and the LAI estimate $L_{\mathrm{G}}$ explains about $80 \%$ of the variation in coniferous stands and about $50 \%$ of the variance in deciduous stands. The degree to which true LAI can be estimated, however, also depends on the amount of branch- and tree-level clumping in the stands.

(6) Multiple regressions, where estimated LAI is predicted as a function of various spectral bands, generate the strongest relationships.
(7) The best single bands for LAI estimation in coniferous stands are the middle-infrared bands, and the best vegetation index is the moisture stress index (MSI = TM5/TM4). MSI is also one of the best indices for deciduous forests.

(8) The best single band for LAI estimation in deciduous stands is TM4, and the best index is the simple ratio (SR).

\section{Acknowledgments}

The study was financed by the Swedish National Space Board (SNSB). We are grateful to Richard Stenström and Pontus Olofsson for help with the field data collection, and to Chris Kucharik for commenting on our LAI computations. We would also like to thank Thomas Persson at the Swedish Meteorological and Hydrological Institute (SMHI) for providing us with meteorological data for the atmospheric correction.

\section{References}

Antunes, M. 2001. Downloading the 6s model adapted for atmospheric corrections of binary images. Available from <http://www.ltid.inpe.br/ dsr/mauro/6s/> [cited 5 Mar. 2001].

Ardö, J. 1992. Volume quantification of coniferous forest compartments using spectral radiance recorded by Landsat Thematic Mapper. International Journal of Remote Sensing, Vol. 13, pp. 1779-1786.

Berenson, M.L., Levine, D.M., and Goldstein, M. 1983. Intermediate statistical methods and applications. Prentice-Hall Inc., Englewood Cliffs, N.J.

Black, T.A., Chen, J.-M., Lee, X., and Sagar, R.M. 1991. Characteristics of shortwave and longwave irradiances under a Douglas-fir forest stand. Canadian Journal of Forest Research, Vol. 21, pp. 1020-1028.

Blackburn, G.A. 1999. Relationship between spectral reflectance and pigment concentrations in stacks of deciduous broadleaves. Remote Sensing of Environment, Vol. 70, pp. 224-237.

Bonan, G.B. 1993. Importance of leaf area index and forest type when estimating photosynthesis in boreal forests. Remote Sensing of Environment, Vol. 43, pp. 303-314.

Boyd, D.S., Wicks, T.E., and Curran, P.J. 2000. Use of middle infrared radiation to estimate the leaf area index of a boreal forest. Tree Physiology, Vol. 20, pp. $755-760$.

Broge, N.H., and Leblanc, E. 2001. Comparing prediction power and stability of broadband and hyperspectral vegetation indices for estimation of green leaf area index and canopy chlorophyll density. Remote Sensing of Environment, Vol. 76, pp. 156-172.

Brown, L., Chen, J-M., Leblanc, S.G., and Cihlar, J. 2000. A shortwave infrared modification to the simple ratio for LAI retrieval in boreal forests: an image and model analysis. Remote Sensing of Environment, Vol. 71, pp. $16-25$.

Búrques, A., Martínez-Yrízar, A., and Núñez, S. 1999. Sonoran Desert productivity and the effect of trap size on litterfall estimates in dryland vegetation. Journal of Arid Environments, Vol. 43, pp. 459-465. 
Butera, M.K. 1986. A correlation and regression analysis of percent canopy closure versus TMS spectral response for selected forest sites in the San Juan National Forest, Colorado. IEEE Transactions on Geoscience and Remote Sensing, Vol. 24, pp. 122-129.

Chen, J.M. 1996. Optically-based methods for measuring seasonal variation of leaf area index in boreal conifer stands. Agricultural and Forest Meteorology, Vol. 80, pp. 135-163.

Chen, J.M., and Black, T.A. 1991. Measuring leaf area index of plant canopies with branch architecture. Agricultural and Forest Meteorology, Vol. 57, pp. 1-12.

Chen, J.M., and Black, T.A. 1992. Defining leaf area index for non-flat leaves. Plant, Cell and Environment, Vol. 15, pp. 421-429.

Chen, J.M., and Cihlar, J. 1995. Plant canopy gap-size analysis theory for improving optical measurements of leaf-area index. Applied Optics, Vol. 34, pp. 6211-6222.

Chen, J.M., and Cihlar, J. 1996. Retrieving leaf area index of boreal conifer forests using Landsat TM images. Remote Sensing of Environment, Vol. 55, pp. $153-162$.

Chen, J.M., Rich, P.M., Gower, S.T., Norman, J.M., and Plummer, S. 1997. Leaf area index of boreal forests: theory, techniques, and measurements. Journal of Geophysical Research, Vol. 102, pp. 29429 - 29443.

Chen, J.M., Pavlic, G., Brown, L., Cihlar, J., Leblanc, S.G., White, H.P., Hall, R.J., Peddle, D.R., King, D.J., Trofymow, J.A., Swift, E., Van der Sanden, J., and Pellikka, P.K.E. 2002. Derivation and validation of Canada-wide coarse-resolution leaf area index maps using high-resolution satellite imagery and ground measurements. Remote Sensing of Environment, Vol. 80 , pp. $165-184$.

Cihlar, J., Chen, J., and Li, Z. 1997. Seasonal AVHRR multichannel data sets and products for studies of surface-atmosphere interactions. Journal of Geophysical Research, Vol. 102, pp. 29625 - 29640.

Comins, H.N., and McMurtrie, R.E. 1993. Long-term response of nutrientlimited forests to $\mathrm{CO}_{2}$ enrichment; equilibrium behavior of plant-soil models. Ecological Applications, Vol. 3, pp. 666-681.

Curran, P.J., Dungan, J.L., and Gholtz, H.L. 1992. Seasonal LAI in Slash Pine estimated with Landsat TM. Remote Sensing of Environment, Vol. 39, pp. 3-13.

Eklundh, L., Harrie, L., and Kuusk, A. 2001. Investigating relationships between Landsat ETM+ sensor data and leaf area index in a boreal conifer forest. Remote Sensing of Environment, Vol. 78, pp. 239-251.

Elvidge, C.D., and Zhikang, C. 1995. Comparison of broad-band and narrowband red and near-infrared vegetation indices. Remote Sensing of Environment, Vol. 54, pp. 38-48.

Fassnacht, K.S., Gower, S.T., MacKenzie, M.D., Nordheim, E.V., and Lillesand, T.M. 1997. Estimating the leaf area index of north-central Wisconsin forests using the Landsat thematic mapper. Remote Sensing of Environment, Vol. 61, pp. 229-245.

Gemmel, F., and Varjo, J. 1999. Utility of reflectance model inversion versus two spectral indices for estimating biophysical characteristics in a boreal forest test site. Remote Sensing of Environment, Vol. 68, pp. 95-111.

Goetz, S.J., and Prince, S.D. 1996. Remote sensing of net primary production in boreal forest stands. Agricultural and Forest Meteorology, Vol. 78, pp. 149-179.

Gower, S.T., and Norman, J.M. 1991. Rapid estimation of leaf area index in conifer and broad-leaf plantations. Ecology, Vol. 72, pp. 1896-1900.
Gower, S.T., Kucharik, C.J., and Norman, J.M. 1999. Direct and indirect estimation of leaf area index, $f_{\mathrm{APAR}}$ and net primary production of terrestrial ecosystems. Remote Sensing of Environment, Vol. 70, pp. 29-51.

Grelle, A., and Lindroth, A. 1996. Eddy-correlation system for long term monitoring of fluxes of heat, water vapour, and $\mathrm{CO}_{2}$. Global Change Biology, Vol. 2, pp. 297-307.

Gupta, R.K., Prasad, T.S., and Vijayan, D. 2000. Relationship between LAI and NDVI for IRS LISS and LANDSAT TM bands. Advances in Space Research, Vol. 26, pp. 1047-1050.

Horler, D.N., and Ahern, F.J. 1986. Forestry information content of thematic mapper data. International Journal of Remote Sensing, Vol. 7, pp. 405-428.

Huete, A.R. 1988. A soil-adjusted vegetation index (SAVI). Remote Sensing of Environment, Vol. 25, pp. 295-309.

Jordan, C.F. 1969. Derivation of leaf-area index from quality of light on the forest floor. Ecology, Vol. 50, pp. 663-666.

Kaufman, Y.J., and Remer, L.A. 1994. Detection of forests using mid-IR reflectance: an application for aerosol studies. IEEE Transactions on Geoscience and Remote Sensing, Vol. 32, pp. 672-683.

Kaufman, Y.J., and Tanré, D. 1992. Atmospherically resistant vegetation index (ARVI) for EOS-MODIS. IEEE Transactions on Geoscience and Remote Sensing, Vol. 30, pp. 261-270.

Kramer, H.J. (Editor). 1996. Observation of the Earth and its environment. Survey of missions and sensors. Springer-Verlag, Berlin. 960 pp.

Kucharik, C.J., Norman, J.M., and Gower, S.T. 1998. Measurements of branch area and adjusting leaf area index indirect measurements. Agricultural and Forest Meteorology, Vol. 91, pp. 69-88.

Kucharik, C.J., Norman, J.M., and Gower, S.T. 1999. Characterization of radiation regimes in nonrandom forest canopies: theory, measurements, and a simplified modeling approach. Tree Physiology, Vol. 19, pp. 695-707.

Lagergren, F., and Lindroth, A. 2002. Transpiration response to soil moisture in pine and spruce trees in Sweden. Agricultural and Forest Meteorology, Vol. 112, pp. 67-85.

Landsberg, J.J., and Waring, R.H. 1997. A generalized model of forest productivity using simplified concepts of radiation-use efficiency, carbon balance and partitioning. Forest Ecology and Management, Vol. 95, pp. 209-228.

LI-COR, Inc. 1992. LAI-2000 plant canopy analyzer operating manual. LICOR, Inc., Lincoln, Nebr.

Markham, B.L., and Barker, J.L. 1987. Thematic Mapper bandpass solar exoatmospheric irradiances. International Journal of Remote Sensing, Vol. 3, pp. 517-523.

Marklund, L.G. 1988. Biomassafunktioner för tall, gran och björk $i$ Sverige. Institutionen för skogstaxering, Sveriges Lantbruksuniversitet, Umeå, Sweden, Rapport 45.

Medlyn, B.E. 1998. Physiological basis of the light use efficiency model. Tree Physiology, Vol. 18, pp. 167-176.

Miller, J.B. 1967. A formula for average foliage density. Australian Journal of Botany, Vol. 15, pp. 141-144.

Nemani, R., Pierce, L., Running, S., and Band, L. 1993. Forest ecosystem processes at the watershed scale: sensitivity to remotely-sensed leaf area index estimates. International Journal of Remote Sensing, Vol. 14, pp. 2519-2534. 
Nilson, T. 1971. A theoretical analysis of the frequency of gaps in plant stands. Agricultural Meteorology, Vol. 8, pp. 5-24.

Nilson, T. 1999. Inversion of gap frequency data in forest stands. Agricultural and Forest Meteorology, Vol. 98-99, pp. 437-448.

Nilson, T., Anniste, J., Lang, M., and Praks, J. 1999. Determination of needle area indices of coniferous forest canopies in the NOPEX region by groundbased optical measurements and satellite images. Agricultural and Forest Meteorology, Vol. 98-99, pp. 449-462.

Peddle, D.R., Hall, F.G., and LeDrew, E.F. 1999. Spectral mixture analysis and geometric-optical reflectance modeling of boreal forest biophysical structure. Remote Sensing of Environment, Vol. 67, pp. 288-297.

Peterson, D.L., Spanner, M.A., Running, S.W., and Teuber, K.B. 1987. Relationship of Thematic Mapper simulator data to leaf area index of temperate coniferous forests. Remote Sensing of Environment, Vol. 22, pp. 323-341.

Pinty, B., and Verstraete, M.M. 1992. GEMI: a non-linear index to monitor global vegetation from satellites. Vegetatio, Vol. 101, pp. 15-21.

Rondeaux, G., Steven, M., and Baret, F. 1996. Optimization of soil-adjusted vegetation indices. Remote Sensing of Environment, Vol. 55, pp. 95-107.

Ross, J. 1981. The radiation regime and architecture of plant stands. Dr. W. Junk Publishers, The Hague, The Netherlands.

Rouse, J.W.J., Haas, R.H., Schell, J.A., and Deering, D.W. 1974. Monitoring vegetation systems in the Great Plains with ERTS. In Proceedings of the 3rd Earth Resources Technology Satellite-1 Symposium, 10-14 Dec. 1973, Washington, D.C. Edited by S.C. Freden, E.P. Marcanti, and M.A. Becker. NASA SP-351, Scientific and Technical Information Office, NASA, Washington, D.C. pp. 309-317.

Running, S.W., and Gower, S.T. 1991. FOREST-BGC, a general model of forest ecosystem processes for regional applications II. Dynamic carbon allocation and nitrogen budgets. Tree Physiology, Vol. 9, pp. 147-160.

Running, S.W., and Nemani, R.R. 1988. Relating seasonal patterns of the AVHRR vegetation index to simulated photosynthesis and transpiration of forests in different climates. Remote Sensing of Environment, Vol. 24, pp. 347-367.

Smolander, H., and Stenberg, P. 1996. Response of LAI-2000 estimates to changes in plant surface area index in a Scots pine stand. Tree Physiology, Vol. 16, pp. 345-349.

Spanner, M.A., Pierce, L.L., Peterson, D.L., and Running, S.W. 1990a. Remote sensing of temperate coniferous forest leaf area index. The influence of canopy closure, understorey vegetation and background reflectance. International Journal of Remote Sensing, Vol. 11, pp. 95-111.

Spanner, M.A., Pierce, L.L., Running, S.W., and Peterson, D.L. 1990b. The seasonality of AVHRR data of temperate coniferous forests: relationship with leaf area index. Remote Sensing of Environment, Vol. 33, pp. 97-112.

Stenberg, P. 1996. Simulations of the effects of shoot structure and orientation on vertical gradients in intercepted light by conifer canopies. Tree Physiology, Vol. 16, pp. 99-108.

Stenberg, P., Kuuluvainen, S.K., Grace, J.C., Jokela, E.J., and Gholz, H.L. 1994a. Crown structure, light interception and productivity of pine trees and stands. Ecological Bulletins, Vol. 43, pp. 20-34.

Stenberg, P., Linder, S., Smolander, H., and Flower-Ellis, J. 1994b. Performance of the LAI-2000 plant canopy analyzer in estimating leaf area index of some Scots pine stands. Tree Physiology, Vol. 14, pp. 981-995.
Tucker, C.J., and Sellers, P.J. 1986. Satellite remote sensing of primary production. International Journal of Remote Sensing, Vol. 7, pp. 13951416.

Turner, D.P., Cohen, W.B., Kennedy, R.E., Fassnacht, K.S., and Briggs, J.M. 1999. Relationships between leaf area index and Landsat TM spectral vegetation indices across three temperate zone sites. Remote Sensing of Environment, Vol. 70, pp. 52-68.

Vermote, E.F., Tanre, D., Deuze, J.L., Herman, M., and Morcrette, J.J. 1997. Second simulation of the satellite signal in the solar spectrum, $6 \mathrm{~S}-$ an overview. IEEE Transactions on Geoscience and Remote Sensing, Vol. 35, pp. 675-686.

Vogelmann, J.E. 1990. Comparison between two vegetation indices for measuring different types of forest damage in the northeastern United States. International Journal of Remote Sensing, Vol. 11, pp. 2281-2297.

Welles, J.M. 1990. Some indirect methods of estimating canopy structure. Remote Sensing Reviews, Vol. 5, pp. 31-43. 